\title{
THE REVENUE CODE AND A CHARITY'S POLITICS
}

The recent withdrawal of tax exempt status from the Fellowship of Reconciliation (FOR), ${ }^{1}$ a pacifist organization, has focused attention on the proper interpretation to be given those sections of the Internal Revenue Code which govern the extent of political activities permissible to tax-exempt charitable organizations. $^{2}$ To qualify for exemption under the Code, charitable organizations are required to be organizations

... organized and operated exclusively for religious, charitable, scientific, testing for public safety, literary, or educational purposes . .. no substantial part of the activities of which is carrying on propaganda, or otherwise attempting to influence legislation, and which does not participate in, or intervene in (including the publishing or distributing of statements), any political campaign on behalf of any candidate for public office. $^{3}$

Not only are such organizations exempt from federal taxation; the individual donor, within certain limits, can deduct contributions to them from his personal income. ${ }^{4}$ The task of testing whether a group is beyond the pale of permissible political activity falls in the first instance to the Internal Revenue Service (IRS). ${ }^{5}$ It has read the statute so as to give itself maximum discretion to deny exempt status. Concentrating on the statute's language of exclusivity of purpose, the IRS has enunciated a policy of disqualifying any

1. Letter from Director, Tax Rulings Division, Internal Revenue Service, to the Fellowship of Reconciliation, Nyack, New York, January 10, 1963, P-H FED. TAxes CUR. DEC. \ 54,825 (hereinafter referred to as Letter Ruling).

2. New York Times, May 25, 1963, p. 24, col. 1. See generally Clark, The Limitation on Political Activities: A Discordant Note in the Law of Charities, 46 VA. L. REv. 439 (1960) ; Note, Income Tax Disadvantages of Political Activities, 57 Colum. L. REv. 273 (1957); Note, The Effect of Legislative Activity on the Tax Status of Religions, Charitable and Scientific Organizations, 18 Онго Sт. L.J. 414 (1957); and Note, Charities, League of Women Voters, 39 TEXAs L. REv. 525 (1961).

3. INT. REv. CODE of 1954, § 501(c)(3) (hereinafter, all section references are to the Internal Revenue Code of 1954, as amended).

4. Section 170 (c) (2) (deductible from personal income); see also $\S \S 2055$ (a) (2) (deductible from value of gross estate), 2106 (a) (2) (A) (ii) (deductible from value of gross estate of decedent nonresident) and 2522(a) (2) (deductible from the value of all gifts). The amount of the deduction from personal income is limited by $\S 170(\mathrm{~b})$.

In the general body of the text, the privileges of deductibility and exemption from taxation will be referred to collectively as the privilege of being "preferred" or "exempt."

5. Rev. Proc. 62-30, 1962-2 Cuar. BuLl. 512, describes the present procedure by which organizations apply to the Internal Revenue Service for classification as exempt. Organizations approved by the Service are included in the Cumulative List, U.S. TREASury Departarent, Organizations Described in Section 170 (c) of The Internal REVENUE CoDE OF 1954 (1962), and contributions to them are automatically allowable. 
organization which has "purposes" which can be classified as political. ${ }^{6}$ In pursuit of this policy, the Service seems to have ignored completely that part of the section which requires that an organization to qualify cannot be engaged, to a substantial degree, in "carrying on propaganda, or otherwise attempting, to influence legislation." "This provision suggests an approach less discretionary than the IRS's, oriented to specific activities and subject to quantification.

The difficulties of the IRS's position are reflected in its recent ruling in FOR. The Fellowship of Reconciliation was founded in 1915 "as a movement of Christian protest against war, and of faith in a better way than violence for the solution of all conflicts." It publishes a periodical, conducts meetings, and produces books, pamphlets, films and tapes, to further its pacifist beliefs. FOR has also opposed conscription legislation, the evacuation of the JapaneseAmericans during World War II, and presently is involved in opposing the creation and testing of mass-destruction weapons. ${ }^{9}$ In 1926, the Fellowship was classified as a charitable organization for purposes of federal taxation; it retained this status until January, 1963, when its exemption was withdrawn by the IRS. ${ }^{10}$ Alternative findings, each of which would have supported withdrawal, were made by the IRS. The first was that FOR's goals - the achievement of peace and international reconciliation through love - are political

6. See, e.g., A. M. Blaine Estate, 22 T.C. 1195 (1954) (Foundation for World Government); Rev. Rul. 62-71, 1962-1 Cum. Buls. 85; Rev. Rul. 60-193, 1960-1 Cur. Burr. 195; J. Forstall, 29 B.T.A. 428 (1933) (League of Nations Assn., Inc.); and J. H. Watson, Jr., 27 B.T.A. $462 \cdot(1932)$.

7. There seem to be no reported cases or rulings which have employed the test derived from the 1934 amendment to deny exempt status by finding that an organization is engaged in a substantial amount of propaganda to infuence legislation. Sugarman, The Line Between Education and Propaganda, 3Rd N.Y.U. Conf. on Charitable FounDATrons 173,177 (1957). This probably reflects the fact that at the very least, the IRS's "purpose" test excludes all organizizations" which do engage to a substantial extent in attempts to influence legislation.

8. Feliowsití of Reconciliation, That Men May Live-Statement of Purpose (hereinafter referred to as Pamphlet).

9. Letter Ruling.

10. The Fellowship of Reconciliation was held first to be an exempt organization under $\S 231$ (6) of the Revenue Act of 1924 of January 11, 1926. This ruling was affirmed on June 29, 1938 and October 9, 1941. A reconsideration of this privileged status began in 1959. In January, 1960, FOR submitted a memorandum in opposition to a proposed revocation of its classification under $\S 501$ (c)(3). On February 17, 1961, a letter was written to FOR from the Chief, Exempt Organizations Branch, IRS, notifying them of the grounds for a proposed revocation. Meetings were held and an additional brief was submitted by FOR in September, 1961. Revocation occurred by a letter of January 10,1963 , withdrawing exemption under $\$ 501$ (c) (3) effective the beginning of FOR's fiscal year of May 1, 1962, and denying deductibility of contributions made after the date of the letter. The Fellowship is still soliciting contributions, making the following statement: "Gifts to the Fellowship of Reconciliation have been declared tax-exempt for 37 years and an IRS reversal is now being contested." Pamphlet; Letter Ruling; Hassler (Executive Secretary of FOR), Memo: A Brief History of the Revocation of the FOR's Federal Income Tax Exemption (March 15, 1963). 
in character and, consequently, that FOR is not "organized and operated" exclusively for a charitable purpose. As is usual where the IRS applies its test of "political purpose," no content was given to the meaning of "political."11 And the readiness with which FOR's purposes might still have been found "religious" in nature suggests both the conclusory character of the IRS test and the IRS's continuing use of its discretion to restrict the class of organizations granted privileged status. ${ }^{12}$ The IRS's second finding marked the beginning of what can only be deemed a logical exercise. "Attainment of international peace," FOR's expressed goal, was characterized by the IRS as obtainable only through legislation. This characterization, itself questionable, ${ }^{13}$ implied to the IRS that FOR was to be classified as a non-charitable

11. See cases cited note 6 supra.

12. Some courts have held that organizations with "political" purposes may still be characterized as "religious" for purposes of tax exemption. Girard Trust Co. v. Commissioner, 122 F.2d 108 (3d Cir. 1941) ; Lord's Day Alliance of Pennsylvania v. United States, 65 F. Supp. 62 (E.D. Pa. 1946).

The Service also questioned the religious character of FOR by stating in its Letter Ruling:

Your statement of purpose . . . is worded so as not to exclude from membership those who deny the existence of any deity. This fact alone might well preclude your description as religious.

This position is dubious. The case law supporting it is conflicting. Accord Davis v. Beason, 133 U.S. 333 (1890), and Berman v. United States, 156 F.2d 377 (9th Cir. 1946), cert. denied, 329 U.S. 795 (1946). Contra, United States v. Seeger, 32 U.S.L. WEEK 1115 (2d Cir. Jan. 20, 1964); United States v. Kauten, 133 F.2d 703 (2d Cir. 1943) ; United States $c x$ rel. Philips v. Downer, 135 F.2d 521 (2d Cir. 1943) ; Fellowship of Humanity v. County of Alameda, 153 Cal. App. 2d 673, 315 P.2d 394 (1957); and Washington Ethical Society v. District of Columbia, 249 F.2d 127 (D.C. Cir. 1957). The lack of a rẹquirement of theistic beliefs did not stop a New York state court, in a real estate tax case, from finding that the Fellowship's activities, "although in the minds of many controversial and unorthodox are nevertheless of a religious nature. ..." Ashbrook v. Town of Clarkstown, Supreme Court, Rockland County, New York, September 26, 1962.

It can be argued that a serious constitutional question is created when the IRS favors certain religious beliefs (i.e. theistic) over others (i.e. non-theistic). Everson v. Board of Education, 330 U.S. 1, 15 (1947); American Sugar Refining Co. v. Lotisiana, 179 U.S. 89, 92 (1900) ; United States v. Seeger, 32 U.S.L. WeEx 1115 (2d Cir. Jan. 20, 1964) ; Fellowship of Humanity v. County of Alameda, 153 Cal. App. 2d 673, 693̈, 315, P.2d 394, 406 (1957). See also Note, State Tax Exemptions and the Establishment Clause, 9 StAN. L. REV. 366 (1958).

With such considerations, and given certain standards as to the meaning of religion, 13 ENCYC. Soc. Scr. 237, it would be very reasonable to have concluded that FOR was a religious organization.

13. The IRS's conclusion that FOR's goals could only be achieved by legislation came under sharp criticism by Senators Keating, McGovern and Nelson. 109 CoNG. REC. 7798 and 7842 (daily ed. May 13, 1963) and 109 Cong. Rec. 8305 (daily ed. May 16, 1963). Senator Nelson successfully ridiculed the conclusion by revealing to the Senate a letter he had written to Commissioner Caplin, asking in part the following:

Exactly how did the Internal Revenue Service determine that world peace could be secured only through legislation, and could you give me an example of the legislation needed to bring this about?

109 Cong. Rec. 7798 (daily ed. May 13, 1963). Senator Nelson received no answer. 
"action" organization, defined by Treasury regulations as an organization whose "main or primary objective . . . may be attained only by legislation" and which "advocates or campaigns for, the attainment of such main or primary objective."14 The IRS did not indicate that FOR was presently engaged in any activity connected with the passage of legislation; there was naught but logical "proof" that it was ever likely to do so. ${ }^{15}$ As used in FOR, the "action" organization test could only have served as an elaboration on the "organized and operated exclusively" requirement. ${ }^{16}$ Thus, the Service's emphasis on a broad "purpose" approach is dramatically shown.

It cannot be said with certainty that the IRS's emphasis is wrong - that it involves a departure from what a reasonable man might consider the statutory command. What can be said is that it arrogates to the IRS virtually unrestricted authority to decide who may and may not receive exempt status. The characterization of "purpose" is an elusive matter. There are different orders of purpose: the ultimate end sought is, at one level, a group's "purpose"; at another level, "purpose" includes the means necessary to that end. Leaving "political purpose" undefined, the Treasury has felt free to select indiscriminately among the possible orders of "purpose" in characterizing group purposes. But does the "purpose" of the American Cancer Society become less "educational" or "scientific" when it seeks through the political arena to obtain the education of young people to the dangers of lung cancer? Whether attention is directed to the purpose of preventing cancer, or to the purpose of achieving legislation to aid in the prevention of cancer, determines the answer given. Were the Society's purposes to be deemed not "exclusively" charitable, there would be few groups whose purposes would fall

14. Treas. Reg. \& 1.501(c)(3)-1(c)(3)(iv)(1959). Other definitions not specifically relevant to the FOR case:

a) An organization is an "action" organization if a substantial part of its activities is attempting to influence legislation by propaganda, or otherwise. Treas. Reg. § 1.501 (c) (3)-1(c) (3) (ii) (1959).

b) An organization is an "action" organization if it participates or intervenes, directly or indirectly, in any political campaign on behalf of or in opposition to any candidate for public office. Treas. Reg. § 1.501 (c) (3)-1(c) (3) (iii) (1959).

See generally, 4th N.Y.U. Conf. on Charitable Foundations 197-238 (1959).

15. See Brief for The Fellowship of Reconciliation submitted to the Internal Revenue Service, Exempt Organizations Branch, September, 1961. Here, FOR maintains that it "has not distributed leaflets to legislators nor has it directed persons how best to prepare proposals for changes in the law." In the Fellowship's Supplemental Brief to the Internal Revenue Service, Tax Rulings Division, June, 1963, it is stated that its activities "did not include working directly with members of Congress, or the maintenance of a lobbyist in Washington." Neither statement was denied in the Letter Ruling.

16. It might be argued that this particular "action" organization test is related to the requirement that an organization cannot engage in a substantial amount of "propaganda, or otherwise attempting, to influence legislation," and that the Regulation creates a presumption that an organization does engage in an impermissible amount of such activity. If this were the case, such a presumption should then be rebuttable by an organization's documentation of its activities, and not conclusive as it was in FOR. 
wholly within the preferred class, or whose purposes could not be benefited by legislative action. Given the Treasury approach, continuance or withdrawal of exempt status is a matter of conclusory characterization : the organization's ultimate goal will be emphasized where exemption will continue; the means it adopts or must adopt for achievement, if withdrawal is the intended result.

This discretion has its dangers. There is, of course, the undesirable though inevitable hazard of uncertainty. From the point of view of the organization, uncertainty will often inhibit the sponsorship of activities and programs which might arguably be classed as "political."17 The more dangerous aspect of the discretionary approach is the opportunity for discrimination among organizations on the merits of the goals they seek. Once an organization has qualified for exemption, administrative and revenue limitations combine to render IRS scrutiny of its behavior sporadic at best. ${ }^{18}$ The choice of organizations for review, however, may well not be random. A group like FOR may be singled out for review by an individual revenue agent - ordinarily responsible for initiating the review process - reading the newspaper and shaking his head at the group's beliefs. Or a Congressman, strategically placed, may bring his considerable pressure to bear upon the IRS to the disadvantage of an unpopular group. The conclusory nature of the test applied, the great disparity between the number of exempt organizations and the number of exempt organizations reviewable, and the fact that only the IRS has standing to initiate review and withdrawal of exempt status, heighten the dangers of discriminatory selectivity. ${ }^{19}$ When a broad "purpose" test is employed, it

17. It may be possible in some instances for an organization to obtain a "ruling" from the IRS as to the consequences of a particular activity under Rev. Proc. 62-28, 1962-2 CuM. Bull. 496. But, at best, such a procedure is burdensome and time consuming and does not provide the organization with the flexibility to make quick decisions.

18. Mr. Wormser: Actually, though, you are not adequately staffed and probably could not be to do a complete job of auditing the substance of the performance of those foundations. You rely chiefly on miscellaneous outside information and have to, I suppose.

Mr. Sugarman: . . Our experience has indicated that by and large there are comparatively few of the exempt organizations that really stray from the nature of their original exemption. I am not saying that by way of indicating that doesn't mean we don't have to check them, but I am saying in terms of the revenue consequences of our results in this area are comparatively less productive than others. Accordingly, considering the balance of our total activities, and the budget available to us, we do devote as much as we are able to in this area.

Hearings Before the Special Committee to Investigate Tax-Exempt Foundations and Comparable Organizations, House of Representatives, 83rd Cong., 2d Sess., p. 437 (1954). See note 57 infra for a discussion of the use of the annual reporting requirement to facilitate review of exempt organizations.

19. Once the Service has classified an organization as exempt under $\S 501$ (c) (3), it is said to be "prima facie" evidence of the deductibility of contributions and binding upon the Service until an adverse "ruling." Obviously, no one making a contribution to the exempt organization would wish to challenge this status. And how would a contributor challenge the "ruling" except by refusing to deduct the contribution-an unnoticed act of defiance which would be to his financial detriment. The ordinary taxpayer who might 
becomes impossible for the critic and the court to discover whether discrimination was at work, whether the umbrella of the "purpose" test covered some agent's personal dislike of the organization's purposes or beliefs.

The history of the relevant Code sections is checkered with events which can fairly be characterized as attempts to limit the sweep of the IRS approach. That approach was developed immediately following creation of the charitable deduction in $1917 . .^{20}$ The income tax statutes did not then restrict explicitly the political activities of a charitable organization, but did refer to the necessity for an exclusively religious or charitable purpose. The early Treasury rulings - forerunners of the present IRS approach - imputed to Congress a restriction on political activities by maintaining that such activities were not consistent with organization and operation exclusvely for the exempt purposes. ${ }^{21}$ Organizations engaging in such activities were, therefore, to be denied preferred status. When this Treasury approach came before the courts, it received only qualified approval. In the 1930 case of Slee $v$. Commissioner, ${ }^{22}$ questioning the deductibility of a contribution to the American Birth Control League, Judge Learned Hand acknowledged the necessity of limiting the availability of tax exempt status to politically adventurous or-

disapprove of the Treasury's selection would have no standing to object in court because of ans alleged improper narrowing of the tax base and the subsequent alleged harm to him. Massachusetts v. Mellom, 262 U.S. 447 (1923).

On the other hand, when the IRS denies exempt status to an organization, any contributor to that organization has a means to challenge the "ruling." The contributor would only have to deduct his contribution in his income tax return, have it disallowed by the Treasury, and then challenge the Treasury's position in the courts. Even the organization might seek judicial intervention through an injunction against the Treasury, though this has never yet been tried.

20. Exemption from taxation was included as a part of the Income Tax of 1913. 38 Stat. 166, 172 (1913). At that time an amendment was proposed to allow for the unlimited deduction of charitable contributions but was defeated without debate. 50 CoNG. Rec. 1259 (1913). In 1917, an amendment to allow a deduction of up to 15 per cent of taxable income for charitable contributions was passed. 40 Stat. 330 (1917). There was no discussion about restricting the political activities of charitable organizations when Congress approved this amendment. 55 CoNG. REc. 6728 (1917).

21. ... it was Congress's intention, when providing for the deduction of contributions to educational corporations, not to benefit and assist the aims of one class against another, not to encourage the dissemination of ideas in support of one doctrine as opposed to another, to the profit of one class and to the detriment perhaps of another, but to foster education in its true and broadest sense, thereby advancing the interest of all, over the objection of none.

S. 1362, 2 CuMr. Bul. 152, 154 (1920).

An association engaged in disseminating propaganda to encourage the passage of labor legislation, S. 1362, 2 CuM. Bux.. 152 (1920), and an organization whose purpose was furthering the enactment of prohibition laws and the nomination and election of candidates for office favorable to its work, O.D. 704, 3 Curr. BurL. 240 (1920), were held not entitled to exempt privileges. See also Herbert Fales, 9 B.T.A. 828 (1927) (contributions not deductible to the Mass. Anti-Saloon League, Scientific Temperance Federation).

22. 42 F.2d 184 (2d Cir. 1930). 
ganizations. ${ }^{23} \mathrm{He}$ affirmed the denial of the deduction at issue. But, unlike the Service, he also recognized that tax exempt organizations might need, at times, to engage in activity others might call political, and that some reasonable rule would be required to permit this activity without damage to the tax privilege :

Nevertheless, there are many charitable, literary and scientific ventures that as an incident to their success require changes in the law. A charity may need a special charter allowing it to receive larger gifts than the general law allows. ... A society to prevent cruelty to children, or animals, needs the positive support of law to accomplish its ends. ... We should not think that a society of booklovers or scientists was less "literary" or "scientific" if it took part in agitation to relax taboos upon works of dubious propriety or to put scientific instruments upon the free lists. All such purposes are mediate to the primary purpose and would not, we should think, unclass the promoters. The agitation is ancillary to the end in chief, which remains the exclusive purpose of the association. ${ }^{24}$ The dictum, widely accepted in later cases, ${ }^{25}$ sharply questions the Treasury's assumption that political activities are inconsistent with an exclusively charitable purpose.

In 1934, Congress added to the definition of a qualifying charitable organization the requirement that ". . . no substantial part of the activities of . . . [the organization be] carrying on propaganda, or otherwise attempting, to influence legislation. . . ."28 Unfortunately, there is no legislative history to indicate why this explanation of the permissible scope of activities by an exempt organization was added. ${ }^{27}$ But it would be reasonable to view the amendment as a codification of the Slee dictum and a rejection of the strict Treasury point of view. ${ }^{28}$ As the Treasury's continued enforcement of its

23. Political agitation as such is outside the statute however innocent the aim. ... Controversies of that sort must be conducted without public subvention: The Treasury stands aside from them.

Id. at 185.

24. Ibid.

25. See, e.g., International Reform Fed. v. District Unemployment Compensation Bd., 131 F.2d 341 (D.C. Cir. 1942); Girard Trust Co. v. Commissioner, 122 F.2d 108 (3d Cir. 1941) ; Lord's Day Alliance v. United States, 65 F. Supp. 62 (E.D. Pa. 1946) ; and Old Colony Trust Co. v. Welch, 25 F. Supp. 45 (D. Mass. 1938).

26. 48 Stat. 690 (1934).

27. Nor is the statutory history of this amendment helpful in deciding the appropriate interpretation to be given it. Uncertainty over the desired scope of the amendment, fear of abuses and mistakes in administration, and dissatisfaction with the language of the amendment were present in the short Senate debate. 78 CoNG. REc. 5861, 5959 (1934).

28. A high Treasury official once expressed this view:

The 1934 amendment to the law ... indicated an awareness by the Congress of the tenor of the court decisions ... . and by indirection, a reluctance to hold the line on the basis of the narrow interpretation by the Service of the 101(6) educational exemption.

Congress saw fit only to circumscribe the exemption with a restriction against substantial activities to influence legislation.

Testimony of Norman Sugarman, Assistant Commissioner of Internal Revenue, Hearings 
position has shown; the amendment would otherwise have no practical effect - either in tightening or loosening requirements for exempt status. The amendment varies from Slee only in replacing Slee's "mediate" and "ancillary" test by a more manageable focus upon specific activities and the degree to which the organization engages in them. There is an implicit recognition that political activities and charitable purposes do overlap: to give tax benefits to deserving organizations, some political activity (less than a substantial amount) must be countenanced.

Faced with the Treasury's continued reliance on its pre-1934 position, a number of courts recently have read the 1934 amendment in the suggested restrictive manner - as requiring a focus on the activities of a tax-exempt organization rather than its purposes. ${ }^{29}$ In Dulles $v$. Johnson, ${ }^{30}$ for example, the IRS argued for the denial of favorable tax treatment of contributions to various bar associations on the ground that the donees were blighted with political purposes. The Second Circuit refrained from attempting to classify the purposes of the organization as "political": it satisfied itself that the purposes were at least charitable and that no substantial part of the donees' activity was "propaganda, or otherwise attempting, to influence legislation."31 Other courts, also concentrating on the specific activities of the organization, have reversed the IRS to accord deductible status to contributions to the Louisville League of Women Voters, ${ }^{32}$ the Hamilton County Good Government League, ${ }^{33}$ and the Kentucky Welfare Association ${ }^{34}$ on the ground that a less than substantial portion of these organizations' activities was devoted to influencing legislation. All of these decisions have one common factor: they look to the behavior of an organization, rather than its aims, once it becomes clear that the organization, in general terms, is within the class whose purposes might be characterized as charitable. And in doing so they provide the possibility for evolving standards susceptible of quantification and even-handed administration and review..$^{35}$

Before the Special House Conmittee to Investigate Tax-Exempt Foundations and Comparable Organizations, 83rd Cong. 2d Sess. p. 433 (1954).

29. Dulles v. Johnson, 273 F.2d 362 (2d Cir. 1959); Seasongood v. Commissioner, 227 F.2d 907 (6th Cir. 1955); International Reform Fed. v. District Unemployment Compensation Bd., 131 F.2d 337 (D.C. Cir. 1942) ; Liberty Nat'l. Bank v. United States, 122 F. Supp. 759 (W.D. Ky. 1954) ; Davis v. Commissioner, 22 T.C. 1091 (1952); and Smith v. Commissioner, 3 T.C. 696 (1944).

30. 273 F.2d 362 (2d Cir. 1959).

31. Id. at $365-68$.

The Second Circuit found that activities such as regulation of the unauthorized practice of law, disciplining of members of the legal profession, endorsing candidates for judicial office, and even reporting to the legislature on proposed and existing legislation were beneficial to the public and donations to support them could be construed as charitable.

32. Liberty Nat'l Bank v. United States, 122 F. Supp. 759 (W.D.Ky. 1954).

33. Seasongood v. Commissioner, 227 F.2d 907 (6th Cir. 1955).

34. Davis. v. Commissioner, 22 T.C. 1091 (1952).

35. Seasongood v. Commissioner, 227 F.2d 907,911 (6th Cir. 1955) and International Reform Fed. v. District Unemployment Compensation Bd., 131 F.2d 337 (D.C. Cir. 1942), 
Why has the Treasury persisted in its emphasis upon "purpose" in the face of statutory change and judicial disagreement? One explanation is the Treasury's vigilance against any narrowing of the tax base by expansion of exemptions and deductions. When presented with alternative reasonable interpretations, it will often choose the reading most beneficial to the fisc. But, supposing the present IRS position to be reasonable, the amount of revenue likely to be obtained from denying or withdrawing preferred status in the area of charitable deductions seems insignificant. ${ }^{36}$ Tax revenue will not be obtained from the charitable organization itself upon withdrawal of its exemption, for it is unlikely that such organizations have any "income" for purposes of federal taxation. ${ }^{37}$ Furthermore, so long as organizations which engage in political activities and the dissemination of their beliefs operate on a non-profit basis and provide no benefit to private individuals, the Code permits their classification as civic action or social welfare organizations or as business leagues. ${ }^{38}$ As such they are exempt from taxation but individual contributions to them are non-deductible. Any real revenue significance flowing from withdrawal of preferred status, then, derives from denying the deduction of individual contributions to charitable organizations. But additional revenue will accrue only if people continue donating to the no-longer-exempt organization or use the monies they would have contributed for non-deductible purposes. Both hypotheses seem unrealistic. Since the IRS's investigation of already exempt organizations is only sporadic, many charitable organizations engaging in marginally "political" activities still enjoy preferred status. ${ }^{39}$

suggest that the only referent for the 1934 amendment should be lobbying as it is restricted by legislation. Seasongood suggested the use of United States v. Harriss, 347 U.S. 612 (1954) as a possible source for a definition of lobbying. 227 F.2d at 911-12.

36. See note 18 supra.

37. There do not appear to be any rulings or cases which hold that an organization, such as FOR, constituted to be non-profit and providing no benefit to any individual, has "income" for purposes of $\S 61$. Contributions from individuals may be excluded from income as gifts under $\$ 102$.

The status of earnings from property held by such an organization is unclear as is the allowable deductions against such revenue. The Fellowship has, at the moment, no specific exemption from taxation, simply maintaining, "it has no income in any taxable year." Letter From Representative of the Fellowship of Reconciliation to the Yale Laze Joutrnal, Oct. 28, 1963.

38. "Civic leagues or organizations not organized for profit but operated exclusively for the promotion of social welfare" under $\S 501$ (c) (4) and "Business leagues ... not organized for profit and no part of the net earnings of which inures to the benefit of any private shareholder or individual" under $\$ 501(c)(6)$ are exempt from taxation and are not restricted in their political activities beyond those deemed incompatible with the organization's purposes. See Rev. Rul. 177, 1961-2 Cum. Bull. 117, in which a $\$ 501$ (c) (6) business league is allowed to engage solely in attempts to influence legislation.

39. The Fellowship of Reconciliation, in its Memorandum of January; 1960, and its Brief of September, 1961 to the Internal Revenue Service, Exempt Organizations Branch, mentioned a number of organizations, presently exempt, which could be said to engage in marginal political activities. For example:

Anti-Defamation League of B'Nai B'rith

Christian Anti-Communism Crusade 
Consequently, a potential contributor, who finds his previous favorite stripped of its exempt status, can probably locate a tax-exempt organization engaged in similar activities. ${ }^{40}$ Many contributors, moreover, are motivated more by the joy of giving (with the concomitant tax advantages) than by desire to accomplish specific goals. Such donors' contributions are even more fungible, for the elimination of one object of bounty is not apt to reduce the total of charitable gifts. Hence, it would appear that the Treasury's restriction of the political activities of preferred organizations cannot be vindicated as a protection of the revenue function.

Some justification for the Treasury's position may rest on another ground : the policy against subvention, government underwriting of political activities. This policy was articulated and relied upon by Judge Hand in Slee, ${ }^{\mathbf{1 1}}$ and imputed to Congress in the early Treasury Regulations which first established the IRS's present position. ${ }^{42}$ Congress was said to have recognized that

[government ought] not to benefit and assist the aims of one class against another, not to encourage the dissemination of ideas in support of one doctrine as opposed to another. . . .43

If political beliefs could be said to vary by income groups, a progressive tax establishment would require total non-deduction of contributions to politicallyoriented groups. The advantages of deductions to charitable organizations vary directly with the bracket of the taxpayer who itemizes his contributions. For those taxpayers who do not itemize their contributions, the allowance of a deduction would have no effect on the after-tax cost of their contributions. ${ }^{44}$ Thus, the cost of political participation would differ from individual to individual, with the wealthiest individuals (by and large) having the lowest cost of participation. The Treasury's broad political purpose test can be viewed as a response to this problem of subvention. Non-exemption of any organiza-

Christian Freedom Foundation, Inc.

General Board of Christian Social Concerns of the Methodist Church

Zionist Organization

The House Select Committee on Lobbying Activities in a 1950 report concluded that the American Enterprise Association, the Public Affairs Institute and the Foundation for Economic Education, Inc., characterized as research organizations, should be subject to the provisions of the Federal Lobbying Act. H.R. REP. No. 3233, 81st Cong., 2d Sess. 19 (1950). These organizations still enjoy tax-exempt status. Cumulative List. U.S. Treasury Department, Organizations Described in Section 170(c) of the Internal REVENUE CODE OF 1954 (1962).

40. The potential contributor to FOR, who still wishes to make deductible contributions to organizations engaged in similar activities, might give to one of the many pacifist fellowships affiliated with specific church organizations or to the American Friends Service Committee, an organization which often sponsors pacifist activities.

41. See note 23 supra.

42. See note 21 supra.

43. S. 1362, 2 Curr. Butr. 152, 154 (1920).

44. In 1960 , only $24,083,000$, or 39.5 per cent of the total $61,028,000$ returns filed with the IRS, had itemized deductions. U.S. Departarent of Inconre, Statistics of Incoure ... 19602 (Preliminary) (1962). 
tion which might arguably be engaged in political activities, prevents the use of such organizations "at government expense" as conduits for individual efforts in the political sphere. ${ }^{45}$

In the abstract, this plea for neutrality seems meritorious. Even if it were applied across the board to individuals and businesses, however, the abstract goal could not presently be achieved. Irrespective of the danger of abuses of discretion leading to favoritism of some "political purposes" over others, the sporadic nature of IRS enforcement insures that subvention will remain for those organizations whose activities the IRS does not happen to review. ${ }^{48}$ In fact, the policy is no longer applied across the board; tax neutrality, in the abstract, is no longer a universal concept. By revision of Code Section 162(e) by the Revenue Act of 1962, Congress explicitly chose to allow some subvention for businesses, which may now deduct certain expenses incurred in legislative activities. ${ }^{47}$ The question of the deductibility of these expenses had been raised, just previous to enactment, in the case of Cammarano $v$. United

45. Professor Sacks has framed the problem and a possible solution in the following manner :

For me, the difficulty lies not in the nature of philanthropy but in the possible distortion of the legislative process. . . . If I imagined a universe of foundations, all of roughly the same financial size and power, then I would embrace all the gains to our society and to our democratic processes that would come from freeing foundations to participate legislatively. But, if I envisage as I do, great disparities of financial resources, then $I$ have to recognize that change in the law may be a result of these resources, rather than of the free play of ideas. ... If one can hope for change in the tax law ... I suggest that it would be desirable to permit a tax deduction, limited not only in percentage but in amount, for contributions to organizations that desire to engage in legislative activity.

Sacks, Use and Misuse of the Private Foundation, 5th N.Y.U. Conf. on Charitable Foundations 203, 208-09.

Such an approach would require the realignment of charitable organizations within a new scheme of classification in which one group would be allowed deductible contributions but could not engage in political activities, whereas, the other group would only be allowed deductible contributions to a small maximum amount and could engage in political activities. Such a scheme would create, it would seem, many more administrative problems in the classification of organizations for the determination of the allowable deduction than is presently the case.

46. See note 39 sipra.

47. Section 3 of the Revenue Act of 1962. 76 Stat. 973 (1962). Section 3 created a new $\$ 162(e)$ of the INT. REv. CODE of 1954, providing that the following expenses are ordinary and necessary and may be deducted under $\$ 162(a)$ :

(A) in direct connection with appearances before, submission of statements to, or sending communications to, the committees, or individual members, of Congress or of any legislative body of a State . . with respect to legislation or proposed legislation of direct interest to the taxpayer, or

(B) in direct connection with communication of information between the taxpayer and an organization of which he is a member with respect to legislation ... of direct interest. ...

See Weaver, Taxes and Lobbying - The Issue Resolved, 31 GEo. Wast. L. Rev. 938 (1963). 
States; 48 the Supreme Court disallowed the deduction of expenses incurred by a liquor dealer in fighting legislation inimical to his business interests. ${ }^{49}$ Arguing against deductibility, the IRS had recognized and strongly urged that tax neutrality, if it were to be meaningful, had to apply to the whole panoply of participants, including businesses. ${ }^{50}$ The Supreme Court upheld the Service, reaffirming the "sharply defined policy" of Slee against government subvention and extended this policy to businesses as well as to charitable organizations. ${ }^{51}$ The Revenue Act of 1962, by reversing the Supreme Court, not only makes defense of the policy more difficult, but also indicates a changed congressional position on subvention versus encouragement of political participation. ${ }^{52}$ As against any general policy against subvention, the Senate Finance Committee voiced the apparent resolution of Congress, in finding it more desirable

48. 358 U.S. 498 (1959).

49. In Cammarano, petitioners were engaged in the distribution of beer in the State of Washington and their contribution was to finance a campaign to defeat a statewide "initiative" referendum which would have placed the retail sale of wine and beer exclusively in the hand of the state. 358 U.S. at 500 .

In F. Strauss \& Son v. Commissioner, a companion case, petitioner was engaged in the wholesale liquor business in Arkansas. Money was contributed to an organization attempting to defeat an initiative calling for an election of statewide prohibition. 358 U.S. at 502 .

50. In the government's brief, the following argument was made:

At the present time... any campaigns financed by industry to influence legislation cannot be charged to the government by taking these expenses as a deduction. The financing is thus entirely out of the pocket of the concerns involved. This is equally true as to any citizens' organizations which might be formed to conduct similar campaigns since contributions to these campaigns would not qualify as charitable contributions and accordingly are not deductible. The same is true of a labor organization. Thus a tax equilibrium exists. If the expenses of the business community were to become deductible, this tax equilibrium would be upset. While the business community could deduct their expenses, all others could not, even with respect to the same legislation.

Brief for Respondents, p. 12, Cammarano v. United States, 358 U.S. 498 (1959).

This argument was implicitly accepted in the Cammarano decision. On "tax equilibrium" generally, see Sharp, Reflection on the Disallowance of Income Tax Deductions for Lobbying Expenditures, 39 B.U.L. REv. 365 (1959); Hearings Before the Senate Special Committee to Investigate Political Activities, Lobbying and Campaign Contributions, 590-93, 84th Cong., 2d Sess. (1956) and 85th Cong., 1st Sess. (1957).

51. 358 U.S. at 512 .

52. In Section 29 of the Revenue Act of 1962, 76 Stat. 1068 (1962) Congress also evidenced a policy counter to Slee's policy of no subvention. In this section, it was provided that for purposes of $\S 170$ (c) (2) a contribution made during the calendar year 1962 to or for the use of any non-profit organization created and operated exclusively:

(1) to consider proposals for the reorganization of the judicial branch of the government .... and

(2) to provide information, make recommendations and seek public support or opposition as to such proposals

was deductible. Here, Congress seems to be encouraging a specific form of legislative participation. 
that taxpayers who have information bearing on the impact of present laws, or proposed legislation ... are not discouraged in making this information available to Members of Congress or legislators at other levels of Government. 53

Enforcement difficulties, definitional problems, reversals by courts, and the dangers of untoward discretion may convince that the present Treasury position, as exhibited in FOR, should be abandoned. In developing an approach which will tolerate the inevitable political activity of charitable organizations while minimizing discretion, it seems possible to find directions in the Revenue Acts of 1934 and 1962 . Both suggest that activity directed specifically to achieving legislation is the focus of concern over disallowance. Under the Code, as amended by the Revenue Act of 1934, a charitable organization retains exempt status if not engaged to a substantial degree in carrying on "propaganda, or otherwise attempting, to influence legislation." Section 162(e) of the Code, enacted in the Revenue Act of 1962, presents a different solution for the same activities. Deductions are permitted for lobbying expenses if the legislation is "directly" related to the business claiming the deduction," but are not permitted "in connection with any attempt to influence the general public, or segments thereof, with respect to legislative matters, elections, or referendums." Under both amendments, it should be noted, there must be a nexus with legislative matters before the language purports to apply: in the presence of such a nexus, there is some indication that even under the 1934 amendment, "grass roots" campaigns involving the general public might be wholly forbidden. ${ }^{.8}$ But it may be fairly assumed that in the absence of a

53. S. REp. No. 1881, 87th Cong., 2d Sess. (1962).

54. See note 47 supra.

55. Section $162(\mathrm{e})(2)(\mathrm{B})$.

In addition, there is no deduction for monies expended "for participation in, or intervention in, any political campaign on behalf of any candidate for public office. ..." Section $162(\mathrm{e})(2)(\mathrm{A})$.

56. Certain cases have suggested that the 1934 amendment only restricts the amount of lobbying in which an organization engages. Seasongood v. Commissioner, 227 F.2d 907, 911-12 (6th Cir. 1955), and International Reform Fed. v. District Unemployment Compensation Bd., 131 F. 2d 337 (D.C. Cir. 1942). If this view were adopted and if it were thought that the 1934 amendment was the only source of restriction upon an organization's political activities, an anomalous situation would arise. Organizations would be restricted to an insubstantial amount of lobbying to achieve legislative aims, but would be free to achieve these aims by non-lobbying activities - such as sponsorship of large public rallies and radio programs. To avoid this anomaly, the Congressional policy embodied in $\S 162(\mathrm{e})(2)(\mathrm{B})$ might be imputed to the Code provisions dealing with charities as a type of in pari materia. This policy which, as applied to businesses, denies the deduction of attempts to influence the general public with respect to legislative matters might be said to require disqualification for a charitable organization which engaged in any such activities.

If, however, the very narrow reading of the 1934 amendment is incorrect, then the language of the amendment might be read to include both lobbying and "grass roots" 
specific nexus - say, where an organization seeks to educate the public in the desirability of "better government" or "peace" - Congress was not concerned with the dangers of subvention and, hence, disqualification ought not occur. Certainly insistence upon showing of such a nexus would bring both the caseload and the discretion of the IRS within more reasonable limits. By adopting the consistent suggestion that it focus on activity rather than purpose. and by exercising its concern only for activity mediate to the legislative process as the statutes suggest, the IRS could avoid many of the dangers and failings of its present task..$^{57}$

It is certainly true that such an approach would not be without its difficulties. Difficult problems of definition and fact-characterization remain. It may often be difficult to distinguish between "grass roots" activity directed towards specific legislation and general education campaigns without a legislative nexus. ${ }^{58}$ But the improvement in the structure of dealing with these problems may be apparent from a reconsideration of $F O R$ in its light. Initially, the Service would have satisfied itself that FOR's purposes could be classed as religious or charitable, and refrained from asking if they could also be classed as "political." As for the existence of political activities, the IRS would have made two inquiries: whether a substantial amount of the activities of FOR were lobbying or other forms of representation before legislatures; whether FOR is at present engaged in attempts to mold public

legislative activity and that only a less than substantial amount of both types of activity is permitted for exempt organizations.

With either interpretation, success will depend upon the evolution of a list of items which can be characterized as "lobbying" or "grass roots" activity related to legislation. Such specificity will be the only means of minimizing the discretionary power of the IRS.

57. The case of Seasonwood v. Commissioner, 227 F.2d 907 (6th Cir. 1955) holds out hope for a quantitative standard upon which decisions as to the existence of impermissible political activities may be made. In this case, it was observed that

less than $5 \%$ of the time and effort of the League was devoted to the activities that the Tax Court found to be "political." . . . we conclude that the so-called "political activities" of the League were not in relation to all of its other activities substantial, within the meaning of the section.

227 F.2d at 912 .

The use of such a quantitative standard can greatly facilitate the review process and place it on a regularized basis. $\$ 6033$ (b) requires exempt organizations to file an annual return furnishing information on, among other things, gross income and disbursements out of income. Form 990-A, which is now employed for this annual report. could be modified so as to require information about expenditures for lobbying and "grass roots" campaigning for specific legislation. This would provide the IRS with information which could systematically be examined for excessive or suspicious expenditures and other types of irregularities.

58. Such difficulties are already present in $\$ 501$ (c) (3) which prevents an organization from participating in, or intervening in "any political campaign on behalf of any candidate for public office." In both cases, rules are needed to establish what kind of relationship is necessary - between an organization's activity and a candidate for election or a bill pending before a legislature - before such activity will unclass the exempt organization. 
opinion in favor of certain specific legislative changes. From the available evidence, it would seem that the answer to both questions should be "no"; FOR does not appear to have a legislative program, nor is there any "peace" bill before Congress. ${ }^{59}$ As FOR's activities are not being directed to presently debated legislative proposals, a requirement of a specific nexus with legislative action would find them unexceptionable. By reducing the radius of disqualifying activity and by denoting for disqualification activities readily identified, such a requirement would bring the IRS's task closer to the limitations of its revenue and personnel, and so avoid many of the dangers and inconsistencies presently attending administration of the charitable deduction provisions.

59. See note 15 supra. 